\title{
The Contribution of Legs Muscle Power and Dynamic Balance Towards Jump Shot Ability on Senior High School Basketball Players in Padang
}

\author{
F Mukhtarsyaf \\ The Faculty of Sport Science, Universitas Negeri Padang \\ "Corresponding author. Email: fahdm6231@fik.unp.ac.id

\begin{abstract}
The purpose of this study is to find out the contribution magnitude of legs muscle power and dynamic balance to the ability of jump shot Senior High School Basketball players in Padang. Based on the problem, this research method using correlational approach and followed by analyzing the magnitude of contribution of each indicator variable to the predictor variable. To measure the legs muscle power using Sargeant test, dynamic balance using modified Bass Test, and for jump shot ability using speed spot shooting test. The sample involved in this study is 30 people which determined by training experience and frequency of participation in the competitions. The results of this research shows that legs muscle power contributed $22 \%$ toward the ability of jump shot; dynamic balance contributes $20 \%$ toward the ability of jump shot; and legs muscle power along with dynamic balance contributes significantly to $24 \%$ toward jump shot ability. Based on data analysis, it is concluded that the power of legs muscle and dynamic balance must be considered to be included into the training program especially to improve the ability of jump shot of Senior High School Basketball players in Padang.
\end{abstract}

Keywords: Legs muscle, jump shot, basketball

\section{INTRODUCTION}

Basketball was created in early December of 1891 by a professor of physical education and instructor at the International Young Men's Christian Association Training School (YMCA) (now called Springfield College) in Springfield, Massachusetts, USA). Dr. James A. Naismith, he was born in Canada. Naismith creates a game of the task given by Dr. Luther Gulick to form a game that can maintain a level of physical fitness during the long snow in New England. After some experiments, a game called a basketball (Fardi, 1999: 4) was created. One example of a growing sport in the province of West Sumatra in general and in the city of Padang in particular is a basketball. It can be known by the number of basketball clubs that exist starting from the college level, the level of students, sports groups in the community even to elementary school.

Lots of benefits and noble value in exercising, as written in Law no. 3 years (2005) on National Sport System CHAPTER II article 4 mentioned that: The national sport aims to maintain and improve health and fitness, achievement, human quality, inculcate moral values and noble character, sportsmanship, discipline, cultivate and foster unity and national unity, strengthen national resilience, and raise the dignity, dignity and honor of the nation (Kemenegpora, $2007: 6$ ).

Basketball is a game with a complex movement that is a combination of road, running and jump and elements of strength, speed, accuracy, flexibility and others. To be a good basketball athlete, every athlete has to master basic basketball game techniques, because the better an athlete can master these basic techniques, the better the chances of success in achieving victory.

From several theories, the basic techniques of basketball can be divided into: throwing and capturing techniques, dribbling techniques, shooting techniques, pivot movement techniques, lay-up techniques and rebound techniques (Sodikun 1992: 48). On the one hand, Wissel (2000: 2) suggests basic techniques in basketball include dribbling, shooting, passing and catching, footwork, rebounding, moving with the ball, moving without the ball, attacking and defending. Meanwhile, according to Fardi (1999: 24) basic techniques include: throwing and catching, dribbling, shooting, running and stopping, body control, pivoting, and guarding the opponent (guarding). Based on the three opinions above, the basketball game is a sport that requires a number of basic techniques that must be mastered to be able to play it. 
There are eight types of shooting techniques that are often performed athletes basketball based PERBASI (2006: 23), namely: Set shoot, Lay-up shoot, Underhand shoot, Jump shot, Hook shoot, Dunking, Reverse lay-up shoot, Tapping (tip-in). Jump shot is one type of shooting that is very important to use in basketball. If an athlete does a good shot, then it is a dangerous threat for his opponents to score any time the athlete has the ball. For an athlete can do a shot of any situation, for example, while he is dribbling, and receiving bait in silence and move (M. Sajoto 1985: 22).

The jump shot technique is very advantageous because this skill can be done in all areas of the field, so the opposing team can not know when we will be shooting. If this technique can be mastered by an athlete well, then the team will get more opportunities to increase the victory, because the opportunities that arise during the match occurs only a few seconds. Therefore, to maximize the opportunities, an athlete must have good jump shot skills and a quick response to see when the opportunity arises.

In addition, jump shot techniques will be more useful if against the average team has a high posture, of course if we do a shot around the bottom of the ring, it will be easier at the weir or in the block by the opponent. Therefore, to face teams that have a higher body posture, and to gain a winning jump shot technique is a type of shooting that can be used because the athlete can do a jump shot from any situation to get the numbers. In addition the jump shot technique is usually / often done by athletes who get instructions from the coach because it faces a defense that is so tight / difficult in penetrating the opponent's defense.

In a basketball game we certainly do jumping moves, both when doing rebound or jump shot and other techniques. Jump shot is one type of shooting that requires a good jumping ability. Jump shot will be done well if supported by good physical condition too, so as if the high rings will be parallel to us. To be able to do a shot shot required a good physical condition. M. Sajoto (1995: 56) says that the ability of physical conditions include strength (Strength), Endurance, Speed, Flexibility, Aqility, Coordination and Balance. To improve the physical condition there are two ways methodically, is the general physical improvement and special physical improvement. Which include general physical enhancement are: strength, endurance, speed, agility and elasticity. While that includes special physical enhancement is stamina, explosive power, reaction, coordination, precision and balance (Suharno, HP, 1986: 35). Limb muscle explosive power is one of the physical conditions that is a combination of strength and speed. Sports basketball a lot of jumping and sprinting, therefore with an athlete has a good explosive power, then the movements will be done with the maximum. To increase the winning number, an athlete must shoot into the opponent's ring, one with a jump shot. Jump shot is a technique that requires a good explosive power to make the jump, because to jump as high as possible near the basket as high as $3.05 \mathrm{~m}$ required good leg muscle explosion. Therefore, having a good limb muscle explosive power, an athlete will be higher in position to shoot in the air than his opponents, so the opponent will be more difficult to keep the ring from conceding, because it is difficult to stem the shots of his opponent.

In addition, basketball games also require other physical conditions such as balance. Balance is also an important component for jump shooting, from receiving the ball and jumping straight into landing to the same position as the beginning of the jump, requiring good balance. So by having the ability then any movement will be done more leverage. According Suharsono in Hamdani (2003: 12) there are five uses of the balance that is: facilitate to train techniques, prevent injury, awareness of motion, improve motility and motion efficiency in improving performance. Therefore, balance is important in doing a jump shot.

In addition, this dynamic balance is necessary at the time of the shot towards the ring, especially if the shot begins with a leap of one or two feet, whether it is from a position in place or moment of movement. To obtain accuracy in firing, then the player must be able to maintain the balance in such a way, so that posture, and the direction of the ball and others can be done in a controlled manner. In addition, dynamic balance is necessary when making additional movements in the air due to an interrupting opponent when firing.

\section{METHOD}

Research is classified as a quantitative research by using correlational analysis technique followed by calculating the contribution of free variable to dependent variable. The variables associated in this research are dynamic balance (X1), Legs muscle power (X2), while the dependent variable is the ability of jump shot in basketball (Y).

This study was conducted after the approved proposal, which included test the measuring instrument and the implementation of the test, the test of the measuring instrument was performed to test the feasibility of the measuring instrument used. Place of research at Pembangunan senior high school basketball field.

The population in this study were all male basketball player of High School in the city of Padang, who follow the championship "TAX SBC 2011" because this championship takes place every year with the largest number of participants from other championships. Totalplayer who participates ini this Championship were 288 players. 
Based on the opinion of Irawan (1999: 183) if the population $<100$ people, should be taken all as a sample and if the population is spread in several clusters, then taken by Cluster Random Sampling. The sampling schools were chosen by random sampling, as many as 2 schools from each group, so that it was obtained into four schools with a total sample of 48 people (in excess of a minimum sample of 30 people). The sample in this study was determined only athlete son only, with consideration of differences in physical ability between athlete son and female athlete. Out of population, the samples in tis research were 48 players.

In order to collect the data regularly and systematically, there should be clear steps as follows: data is collected by making three data retrieval posts. In order for data collection to be properly monitored, all samples must be finished taking data per post before entering the next post. Heading 1 is for dynamic balance data retrieval, heading 2 for retrieving limb muscle explosive power and heading 3 for data capability jump shot. The test is carried out in the UNP Padang basketball field, where the test is held on the morning of the morning of 17 April 2011. The testee will be given a briefing before taking the test. To speed up research time, the testee is divided into 3 groups. Each group is on each pre-defined post, after completion at heading 1 , the testee moves to the next post of 2 and 3. Before performing the test, the testee is welcome to warm up sufficiently. Test I: test of Legs muscle power (Sargeant test) $\neg$ In this test, the testee first measured his weight by using the scales that have been provided, without wearing shoes. After that, the testee measures the height of Raihan and performs a maximum jump experiment of three occasions (the best jump taken) to measure the jump height. After completing the test, the testee is allowed to rest before doing the 2nd test. Test II: modified Bass test (modified Bass test) $\neg$ The testee prepares for the start (X) circle and after hearing the cues from the researcher, the testee starts performing the test in accordance with the instructions given. After completing the test, the testee is allowed to rest before performing the 3rd test. Test III: test shot shot $\neg$ Testee get ready in the first position ready to do a jump shot test for 1 minute. By doing a jump shot as much as possible from the five positions that have been given.

To collect data tested to testee by using instrument that will be used in this research: Dynamic balance measurement using Modified Bass test. Measurement of Legs muscle power using Sargeant test Test. Measurement of jump shot capability using Speed Spot Shooting Test.

Data analysis techniques used are simple and multiple correlation analysis techniques. Hypotheses 1 and 2 were analyzed by simple correlation and regression, while hypothesis 3 was analyzed by correlation and multiple regression. Before performing an analysis of the above data, the test requirements are: The normality test to determine whether the data came from a normally distributed population was performed by the Lilliefors test. Regression linearity test X1 on Y and $\mathrm{X} 2$ on $\mathrm{Y}$ using simple regression technique. Independent independent variable test, used to determine whether there is contamination between independent variables in relation to the dependent variable. If it does not exist, it means independent. Multiple correlation and regression analysis, and the determination test of this analysis is used to know the contribution of dynamic equilibrium variable (X1) and limb muscle explosive power (X2) simultaneously to the ability of jump shot (Y), significance correlation and regression equation using test $\mathrm{F}$.

\section{RESULT}

Legs muscle power power

Measurement of Legs muscle power power using Sargeant test was conducted on 30 samples, the highest score was 114 and the lowest score was 70, mean $(87,3)$, standard deviation (standard deviation) was 10.35, mode 90, median 87,5 , and complete data distribution can be seen in Table 1 below:

Based on the above frequency distribution table of 30 samples, 6 people $(20 \%)$ had a $70-78.8$ leg muscle explosion and were categorized as excellent, 9 people (30\%) had an explosive limb muscle strength of 78.987,7 and well categorized, 11 people $(36.67 \%)$ had an explosive limb muscle of 87.8-96.7 and moderately categorized, 2 persons $(6.67 \%)$ had an explosive limb muscle of 96.8-105 , 6 and categorized less, 2 people (6.67\%) have explosive limb muscle power of 105.7 114.5 and are categorized very less.

\section{Dynamic Balance}

From the results of dynamic balance measurement test by using Modified Bass test conducted on the sample of 30 samples. In the highest score can be 125 and the lowest score 97, standard deviation 7.38, mean 108.93, 100 and median mode 109.5. The complete leaflets can be viewed in Table 2 .

Table 2. Data Distribution

\begin{tabular}{|c|c|c|c|c|}
\hline \multirow{2}{*}{$\mathrm{Nu}$} & \multirow{2}{*}{ Category } & \multicolumn{2}{|c|}{ Frequency } & \multirow{2}{*}{ Value } \\
\hline & & Abs & Cumm & \\
\hline 1 & $97-102,6$ & 7 & 23,33 & Very Good \\
\hline 2 & $102,7-108,3$ & 7 & 23,33 & Good \\
\hline 3 & $108,4-113,9$ & 10 & 33,33 & Fair \\
\hline 4 & $114-119,6$ & 3 & 10 & Poor \\
\hline 5 & $119,7-125,2$ & 3 & 10 & Very poor \\
\hline \multicolumn{2}{|l|}{$\sum$} & 30 & 100.00 & \\
\hline
\end{tabular}


Based on the above frequency distribution table of 30 samples, 7 people (23.33\%) have a dynamic balance of 97-102.6 and are categorized excellent, 7 people (23.33\%) have a dynamic balance of 102.7-108, 3 and categorized well, 10 people $(33,33 \%)$ have dynamic balance equal to $108,4-113,9$ and categorized medium, 3 person $(10 \%)$ have dynamic balance equal to 114 119,6 and categorized less, 3 person $(10 \%)$ has a dynamic balance of 119.7-125.2 and is categorized very less.

\section{Jump shot ability}

Jump shot capability is measured using Speed Spot Shooting Test. From the tests and measurements obtained the highest score 25 and the lowest score 18 , yielding mean 18.87 , standard deviation 3.39 , mode 16 , median 18, leaflets complete data can be seen in the following Table 3:

Table 3. Data Distribution

\begin{tabular}{|l|l|l|l|l|}
\hline \multirow{2}{*}{$\mathrm{Nu}$} & \multirow{2}{*}{ Category } & \multicolumn{2}{|c|}{ Frequency } & \multirow{2}{*}{ Value } \\
\cline { 3 - 4 } & & Abs & Cumm & \\
\hline 1 & $13-30,4$ & 4 & 13,33 & Very Good \\
\hline 2 & $30,5-17,9$ & 8 & 26,67 & Good \\
\hline 3 & $18-20,4$ & 9 & 30 & Fair \\
\hline 4 & $20,5-22,9$ & 3 & 10 & Poor \\
\hline 5 & $23-25,4$ & 6 & 20 & Very poor \\
\hline$\sum$ & & 30 & 100.00 & \\
\hline
\end{tabular}

Notes.

Abs = Absolute

Cumm = Cummulative

Table 1. Data Distribution

\begin{tabular}{|c|c|c|c|c|}
\hline \multirow{2}{*}{$\mathrm{Nu}$} & \multirow{2}{*}{ Category } & \multicolumn{2}{|c|}{ Frequency } & \multirow{2}{*}{ Value } \\
\hline & & Abs & Cumm & \\
\hline 1 & $70-78,8$ & 6 & 20 & Very Good \\
\hline 2 & $78,9-87,7$ & 9 & 30 & Good \\
\hline 3 & $87,8-96,7$ & 11 & 36,67 & Fair \\
\hline 4 & $96,8-105,6$ & 2 & 6,67 & Poor \\
\hline 5 & $105,7-114,5$ & 2 & 6,67 & Very poor \\
\hline & $\sum$ & 30 & 100.00 & \\
\hline
\end{tabular}

Notes.

Abs = Absolute

Cumm = Cummulative

Based on Table above frequency distribution of 30 samples, 4 people $(13.33 \%)$ had jump shot capability of 13-30.4 and categorized excellent, 8 people $(26.67 \%)$ had a jump shot capability of $30,5-17,9$ and well categorized, 9 people (30\%) have jump shot capability of 18-20,4 and are categorized moderate, 3 persons (10\%) have the ability of jump shot of 20.5-22,9 and categorized less, 6 people (20\%) have 23-25.4 jump shot capability and are categorized very less.
The first hypothesis tested in this study is the Legs muscle powers contributed significantly to the ability of jump shots in a basketball game. To test the hypothesis is done simple correlation analysis. Based on the results of correlation analysis (X1) with (Y) obtained correlation coefficient $\mathrm{r}=0.47$ and coefficient of determination $\mathrm{r} 2=0.22$. In the table looks tcount $=$ 2.82> tTable $0.05=1.7$ This means that there is a significant relationship between Legs muscle power power with the ability of jump shot in game basketball of 0.47 at $95 \%$ confidence level. Then the magnitude contribution of variable Legs muscle power power to the ability of jump shot in the game of basketball is the coefficient of determination $0.22 \times 100 \%=22 \%$.

The second hypothesis tested in this study is explosive muscle power contributes significantly to the ability of jump shots in basketball games. To test the hypothesis is done simple correlation analysis. Based on the results of correlation analysis (X1) with (Y) obtained correlation coefficient $r=0.45$ and coefficient of determination $\mathrm{r} 2=0.20$. In Table look titung $=2.67>$ tTable $0.05=1.7$ This means that there is a significant relationship between Legs muscle power power with the ability of jump shot in game basketball of 0.45 at $95 \%$ confidence level. Then the magnitude contribution of variable Legs muscle power power to the ability of jump shot in the game of basketball is the coefficient of determination $0.20 \times 100 \%=20 \%$.

The third hypothesis tested in this study is the leg muscle explosive power contributes significantly to the ability of jump shot in a basketball game. To test the hypothesis is done simple correlation analysis. Based on the results of correlation analysis (X1) with (Y) obtained correlation coefficient $r=0.49$ and coefficient of determination r2 $=0.24$. In Fig. Table $\mathrm{Ft}=4.27>$ FTable $0.05=3.35$ This means that there is a significant relationship between Legs muscle power power with the ability of jump shot in a basketball game of 0.49 at $95 \%$ confidence level. Then the magnitude contribution of variable Legs muscle power power to the ability of jump shot in the game of basketball is the coefficient of determination $0.24 \mathrm{x}$ $100 \%=24 \%$.

\section{CONCLUSION}

In accordance with the results of data analysis and discussion. it can be concluded that:

1. Limb muscle explosive (X1) contributes to the ability of jump shot (Y). With the correlation $(r)=0.47$, it can be interpreted that the Legs muscle power power contributes $=22 \%$ and the rest is determined by other factors.

2. The dynamic balance (X2) contributes to the ability of jump shot $(Y)$. With the correlation $(r)=0.45$, it can be interpreted that the dynamic balance contributes = $20 \%$ and the rest is determined by other factors. 
3. Limb muscle explosive (X1) and dynamic balance (X2) together contributes to the ability of jump shot (Y) with correlation $(r)=0.49$. Means the two elements are contributing together to the ability of jump shot of $=$ $0.492 \times 100=0.24 \times 100=24 \%$.

\section{REFERENCES}

[1] Ambler, Vic. 1982. Petunjuk Untuk Pelatih dan Pemain Bola Basket. Bandung: CV Pioner.

[2] Arikunto, Suharsimi. 1986. Dasar-Dasar Evaluasi Pendidikan. Jakarta: PT. Bima Aksara.

[3] Arsil. 1999. Pembinaan Kondisi Fisik. Padang: FIK Unp.

[4] Bompa, Tudor O. 1983. Theory And Methodology of Training. $2^{\text {nd }} E d$, Dubuque. Iowa: Kendall/Hunt Publishing Company.

[5] Depdiknas RI. Undang-Undang Republik Indonesia No. 20 Tahun 2003 Tentang Sistem Pendidikan Nasional. Jakarta: Depdiknas.

[6] Dinata, Marta. 2006. Bola Basket. Jakarta: Cerdas Jaya.

[7] Fardi, Adnan. 1999. Basketball Dasar. Fakultas Ilmu Keolahragaan: Universitas Negeri Padang.

[8] Fox, El., Bowers F., Richard and Foss, Merle. 1993. The Physiological Basis for Exercise and Sport. United States of America: Wm. C. Brown Communications, Inc.

[9] Harsono. 1988. Coaching dan Aspek- Aspek Psikologis dalam Coaching. Jakarta: Tambak Kusuma.

[10] http://www.brainyquote.com/quotes/quotes/j/johnf kenn131489.html (Diunduh Tgl 16 September 2010).

[11] http://www.fitness.gov/digest mar2000.htm : The President's Council on Physical Fitness and Sports. Department of Health and Humans Services. Definitions Of Health, Fitness, and Physical Activity. (Diunduh Tgl 16 September 2010).

[12] http://www.topendsports.com/testing/tests/balance -bass.htm (Diunduh Tgl 16 September 2010).

[13] http://www.bothteamsplayedhard.net/wpcontent/uploads/2010/02/lebron-jump-shotcarmelo1.jpg (Diunduh Tgl 22 Desember 2010).

[14] Kementerian Pemuda Dan Olahraga Republik Indonesia, 2005. Panduan Penetapan Parameter Tes pada Pusat Pendidikan dan Pelatihan Pelajar dan Sekolah Khusus Olahragawan. Jakarta: Asisten Deputi Pengembangan Sumber Daya Manusia Keolahragaan Deputi Peningkatan Prestasi Dan IPTEK Olahraga.

[15] Kirby, R and John A. Robert. 1985. Introductory Biomechanics. Ithaca, N.Y. Movement Publication.

[16] Pengurus Daerah Perbasi Jawa Tengah, 1991. Buku Pegangan Pelatih Basketball. Semarang: Pengda Perbasi.

[17] PERBASI. 2006. Basketball Untuk Semua. Jakarta: Perbasi

[18] PERBASI. 2004. Peraturan Permainan Basketball. Jakarta: Perbasi

[19] Safrit Margareth J. 1995. Introduction to measurement in physical education and exercise science. St. Louis missouri .

[20] Sajoto,M. 1995. Peningkatan dan Pembinaan Kekuatan Kondisi Fisik dalam Olahraga. Semarang : Dahara Prize.

[21] Sarumpaet, A. 1992. Permainan Besar. Departemen Pendidikan dan Kebudayaan: Dirjen Pendidikan Tinggi Proyek Pembinaan Tenaga Kependidikan.

[22] Sodikoen, Imam. 1992. Olahraga Pilihan Basketball. Jakarta: Depdikbud

[23] Suharno. 1985. Ilmu Kepelatihan Olahraga. Yogyakarta : Yayasan STO.

[24] Syarifuddin. 2009. Fisiologi Tubuh Manusia: Untuk Mahasiswa Keperawatan. Jakarta. Salemba Medika

[25] Kemenegpora. 2007. Undang-Undang RI No 3 Tahun 2005 Tentang Sistem Keolahragaan Nasional. Jakarta: Biro Humas dan Hukum Kemenegpora RI.

[26] Williardson, J. 2007. Co The President's Council on Physical Fitness and Sports Re Stability Training: Applications to Sports Conditioning Programs. Journal of Strength and Conditioning Research. 21(3):979-985.

[27] Wissel, Hal. 2000. Basketball: Langkah Untuk Sukses. Jakarta: PT. Raja Grafindo Persada.

[28] Wissel, Hal. 1997. Basketball: Dilengkapi dengan Program Pemahiran Teknik dan Taktik. Jakarta: PT. Raja Grafindo Persada.

[29] Wooden, John R, 1979. Practical Modern Basketball. Los Angeles California. 